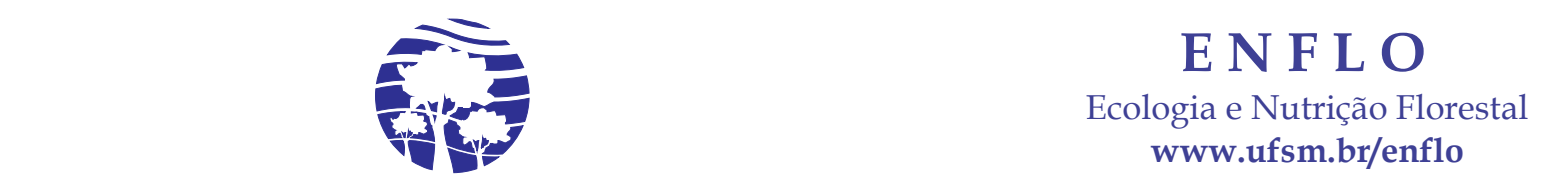

\title{
Impact of water supply on stomatal conductance, light use efficiency and growth of tropical Eucalyptus plantation in Brazil ${ }^{1}$
}

\author{
Marina Shinkai Gentil Otto ${ }^{2}$; Aline Regina Vergani ${ }^{3}$; Antônio Natal Gonçalves ${ }^{4}$; Sérgio Ricardo Silva ; \\ Arthur Vrechi ${ }^{6}$; José Luiz Stape ${ }^{7}$
}

\begin{abstract}
Eucalyptus plantations of Brazil are expanding to areas subjected to water stress, and the water stress is considered a main environmental factor that limit growth and productivity of plantations, this occurrence implies the necessity for advance knowledge about physiological processes of Eucalyptus under different conditions of water availability. In this study, leaf gas exchange and light use efficiency of Eucalyptus under tropical field conditions in Brazil was evaluated to assess the effect of water supply on wood production. The experiment was performed in Eunápolis, Bahia, Brazil (16 ${ }^{\circ} 22^{\prime} 40^{\prime \prime} \mathrm{S}$, $39^{\circ} 34^{\prime} 48^{\prime \prime} \mathrm{W}$ ) and we evaluated two treatments (irrigated and rainfed) of Eucalyptus forest clonal plantation on second rotation, established in August 2009. Leaf gas-exchange parameters were analyzed in 15-month plants using a Portable Photosynthesis System LI-6400xt and to calculate the light use efficiency, the vegetation area index (VAI) were measured through hemispherical photos using a camera - model Cyber shot ${ }^{\circledR}$ Digital Camera Sony DSC - F828 coupled with a Fisheye Lens Opteka 0.22X AF ®. Irrigated trees showed higher biomass increment as a result of higher light use efficiency and lower absorbed photosynthetically active radiation, less carbon allocation to the below-ground; and lower stomatal conductance in relation to vapor pressure deficit (VPD) variation. These results showed that Eucalyptus species are responsive to water supply, and the reduction of stomatal conductance in relation to the VPD variation explains the higher stem biomass increase and greater LUE in the irrigated treatment.
\end{abstract}

Keywords: Photosynthesis; Leaf area index; Irrigation.

\section{Impacto do suprimento de água na condutância estomática, na eficiência do uso da luz e no crescimento de um plantio tropical de Eucalyptus no Brasil}

Resumo: Plantios de Eucalyptus no Brasil estão se expandindo para áreas sujeitas a estresse hídrico, esse fator é a principal razão da redução no crescimento e na produtividade, esta ocorrência implica na necessidade do avanço do conhecimento sobre os processos fisiológicos do Eucalyptus sob diferentes condições de disponibilidade hídrica. Neste estudo foram avaliadas as trocas gasosas foliares e a eficiência do uso da luz para entender o efeito da água na produção de madeira. Este experimento foi realizado em Eunápolis, Bahia, Brasil (16 $\left.22^{\prime} 40^{\prime \prime} \mathrm{S}, 39^{\circ} 34^{\prime} 48^{\prime \prime} \mathrm{W}\right)$, e foram avaliados dois tratamentos (irrigado e não irrigado) em um plantio clonal de Eucalyptus de segunda rotação, estabelecido em Agosto de 2009. Trocas gasosas foliares foram analisadas em plantas com 15 meses de idade utilizando o Sistema Portátil de Fotossíntese LI-6400xt. O cálculo da Eficiência do Uso da Luz (EUL) e do Índice de Área de Vegetação (IAV) foi mensurado através de fotos hemisféricas, utilizando a câmera - modelo Cyber Cyber shot @ Digital Camera Sony DSC - F828 - acopladas com as lentes Fisheye Opteka 0.22X AF ®. As árvores irrigadas apresentaram maior incremento em biomassa como resultado da maior EUL e da menor radiação fotossinteticamente ativa absorvida, menor alocação de carbono abaixo do solo e menor condutância estomática em relação à variação do déficit de pressão de vapor (DPV). Estes resultados mostraram que as espécies de Eucalyptus são responsivas a adição de água e que a redução da sensibilidade estomática em relação à variação do DPV explicam o maior incremento em biomassa e o maior EUL do tratamento irrigado.

Palavras-chave: Fotossíntese; Índice de área foliar; Irrigação.

\footnotetext{
${ }^{1}$ Recebido em 07.10.2016 e aceito para publicação como nota técnica em 19.12.2016.

${ }^{2}$ Engenheira Florestal, Doutoranda Mestranda do Programa de Pós-graduação em Recursos Florestais, Escola Superior de Agricultura "Luiz de Queiroz", Universidade de São Paulo. E-mail: <msgentil@ usp.br>.

${ }^{3}$ Engenheira Florestal, Veracel Celulose S/A. E-mail: <aline.vergani@ veracel.com.br>.

${ }^{4}$ Engenheiro Florestal, Dr., Professor do Departamento de Ciências Florestais, Escola Superior de Agricultura "Luiz de Queiroz", Universidade de São Paulo. E-mail: <natalgon@usp.br>.

${ }^{5}$ Engenheiro Florestal, Dr., Embrapa Milho e Sorgo. E-mail: <sergio.ricardo@embrapa.br>.

${ }^{6}$ Engenheiro Florestal, Esp., 4Tree Agroflorestal.E-mail: <arthur@4tree.com.br>.

${ }^{7}$ Engenheiro Florestal, Dr., Suzano Papel e Celulose. E-mail: <stape@ suzano.com.br>.
} 


\section{Introduction}

In recent decades, the global area planted with Eucalyptus significantly increased (ABRAF, 2013). The supply chain activities of wood industry, including production, harvesting and transportation, contributes in a socially, economically and environmentally terms to the society (ABRAF, 2013). For example, millions of hectares of native forests are being preserved, since for each 1.0 ha of Eucalyptus plantations, approximately 0.97 ha of native forests are preserved in Brazil (ABRAF, 2013).

Although millions of hectares of Eucalyptus are intensively managed worldwide, information regarding physiological processes controlling plant growth and how these processes are regulated by internal and external factors are still needed (STAPE et al. 2004a). The basic premise for the sustainability of planted forests is based on the maintenance of productivity and perpetuation of the dynamic balance between inputs and outputs of water, energy and nutrients (MORRIS et. al, 2005).

The tree growth depends in part on the amount of light absorbed by leaves, the efficiency of using absorbed light to generate photosynthates, and the partitioning of photosynthates to various tissues and functions in the tree (BINKLEY, 2004a). Binkley et al. (2013) showed that forests that are more productive show greater light absorption and higher light use efficiency in comparison to forests that differ in species composition, site fertility and silvicultural managements. In a study with Eucalyptus nitens, Smethurst et al. (2003) observed that the Leaf Area Index (LAI) increased with increasing forest productivity, but this increase in wood growth occurred when the LAI was $4 \mathrm{~m}^{2} \mathrm{~m}^{-2}$ (leaf/soil), indicating that there was a decline in light use efficiency when LAI was higher than $4 \mathrm{~m}^{2} \mathrm{~m}^{-2}$ (leaf/soil).

Other important factor that influences plant growth is the carbon allocation, because this factor plays a critical role in forest ecosystem. Changes in carbon allocation affect both the growth of individual plants, as well as terrestrial biogeochemistry, and an incomplete understanding of carbon allocation currently limits the capacity to model the forest ecosystem metabolism (LITTON et al., 2007).

Brazil plantations are expanding to areas subjected to water stress, and the water stress is considered a main environmental factor that limit growth and productivity of plantations, this occurrence implies the necessity for advance knowledge about physiological processes of Eucalyptus under different conditions of water availability. For this reason, this study aimed to evaluate effect of water supply on stomatal conductance and light use efficiency of Eucalyptus plantations, and were integrate this information into forest productivity models focused on field conditions.

\section{Material and methods}

The experiment was performed in Eunápolis, Bahia, Brazil (16²2'40"S, 39³4'48"W) (Figure 1) on an Ultisol soil with about $37 \%$ clay content in the upper meter. The local climate is Af accordingly to Koppen climate classification (humid tropical), the annual rainfall at this site is $1,250 \mathrm{~mm}$ and the mean annual temperature is 24 ${ }^{\circ} \mathrm{C}$.

Measurements were performed in a Eucalyptus forest clonal plantation on second rotation, established in August 2009 at 4 m x 3 $\mathrm{m}$ spacing. The plantation had received maintenance fertilizers of $\mathrm{N}, \mathrm{P}, \mathrm{K}, \mathrm{Ca}$ and $\mathrm{Mg}$ according to the conventional prescriptions of the company. To eliminate other effects on the tree growth, there was as effective control of pests, diseases and weeds in the plot areas.

The field trial was composed of a completely randomized design with two treatments (irrigated and rainfed) and 4 plots. Each plot consisted of 32 plants (4 lines x 8 plants).

Leaf gas-exchange parameters (stomatal conductance and vapor pressure deficit) were evaluated in 15-month-old plants using a Portable Photosynthesis System LI-6400xt (LiCor Biosciences Inc., Lincoln, NE, USA). Wheater data (Photosynthetically Active Radiation - PAR, temperature and rainfall) were 


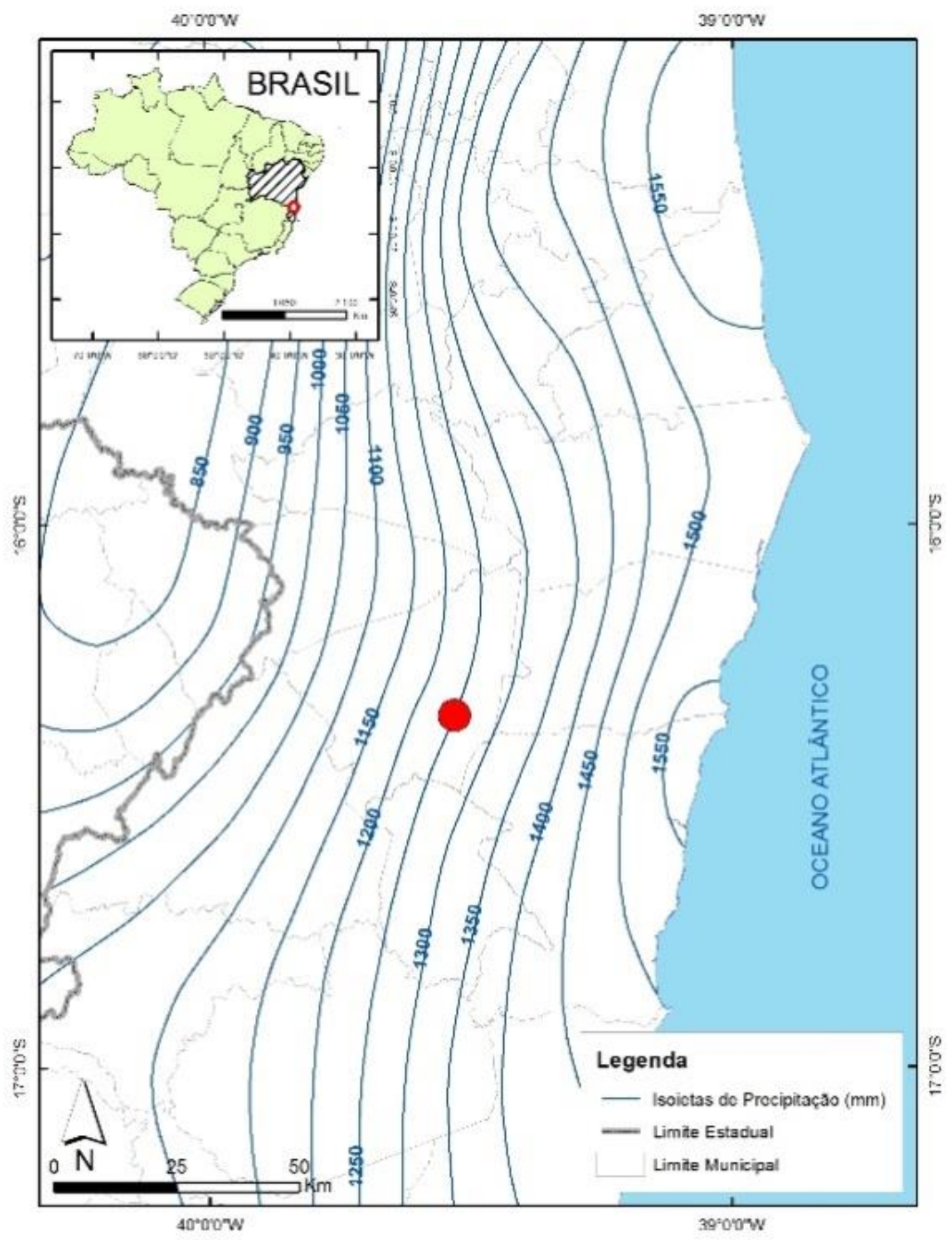

Figure1 - Map with the localization of Eunapolis, Bahia, Brazil associated with the historical rainfall isohyets.

Figura 1 - Mapa com a localização de Eunápolis, Bahia, Brasil associado com as isoietas do histórico de precipitação.

Three trees with average Diameter at Breast Height (DBH) per treatment were used to measure the stomatal conductance (gs). For each tree evaluated, 2 branches and 2 leaves for each branch were selected, resulting in 12 repetitions per treatment. Measurements were performed from 8:00 A.M. to 3:00 P.M., in order to obtain arrange of values of Vapor Pressure Deficit (VPD). The VPD parameter was measured using the Portable Photosynthesis System LI-6400xt during the leaf gas exchange evaluations.

To calculate the light use efficiency, the
Vegetation Area Index (VAI) were measured through hemispherical photography using a camera - model Cyber shot $₫$ Digital Camera Sony DSC - F828 coupled with a Fisheye Lens Opteka 0.22X AF ®. Measurements were performed in 2 points per plot, resulting in 8 measurements per treatment. Images were analyzed in HEMISFER ${ }^{\circledR}$ software to estimate VAI. The Leaf Area Index (LAI) was calculated through a calibration equation developed for the forests of the same study site and age: LAI = EXP $(0.3211+0.4968 * \mathrm{VAI})$ (unpublished 
data).Absorbed Photosynthetically Active Radiation (APAR) was calculated as LambertBeer law $($ LAMBERT, 1760) $($ APAR $=$ PAR * $(1-\exp (-0.5 * \mathrm{LAI})))$.

Finally, Light Use Efficiency (LUE) was calculated using the following equation: LUE = Wood Net Primary Production (WNPP) / APAR (WARING, 1980). When the trees were 15month-old, the Height $(\mathrm{H})$ and Diameter to the Breast Height (DBH) were measured. The stem (WNPP) and root biomass were calculated using allometric equation $\left(\mathrm{WNPP}=\mathrm{a} \cdot \mathrm{DBH}^{\mathrm{b}} \cdot \mathrm{H}^{\mathrm{c}}\right.$; where $a=0.027, b=2.221$ and $c=0.625$ and Root biomass $=\mathrm{a} . \mathrm{WNPP}^{\mathrm{b}}$, where $\mathrm{a}=0.6691$ and $b=0.7858$ ) obtained from a previous forest experiment, accordingly to Ryan et al. (2010).
The results were submitted to Analysis of Variance (ANOVA), followed by Tukey's mean comparison test $(\mathrm{P}<0.05)$, using the SAS software.

From August 2009 to October 2010 the total precipitation was $1522 \mathrm{~mm}$. For irrigated treatment, water was applied with drip hose distributed evenly among the trees and supplied an additional $989 \mathrm{~mm}$. The irrigation system was used to guarantee a minimum input of $40 \mathrm{~mm}$ week $^{-1}$, based on an average potential evapotranspiration of $35 \pm 2 \mathrm{~mm} \mathrm{week}^{-1}$. The average temperature during this period was 23 ${ }^{\circ} \mathrm{C}$, maximum of $26^{\circ} \mathrm{C}$ and minimum of $19^{\circ} \mathrm{C}$ (Figure 2).

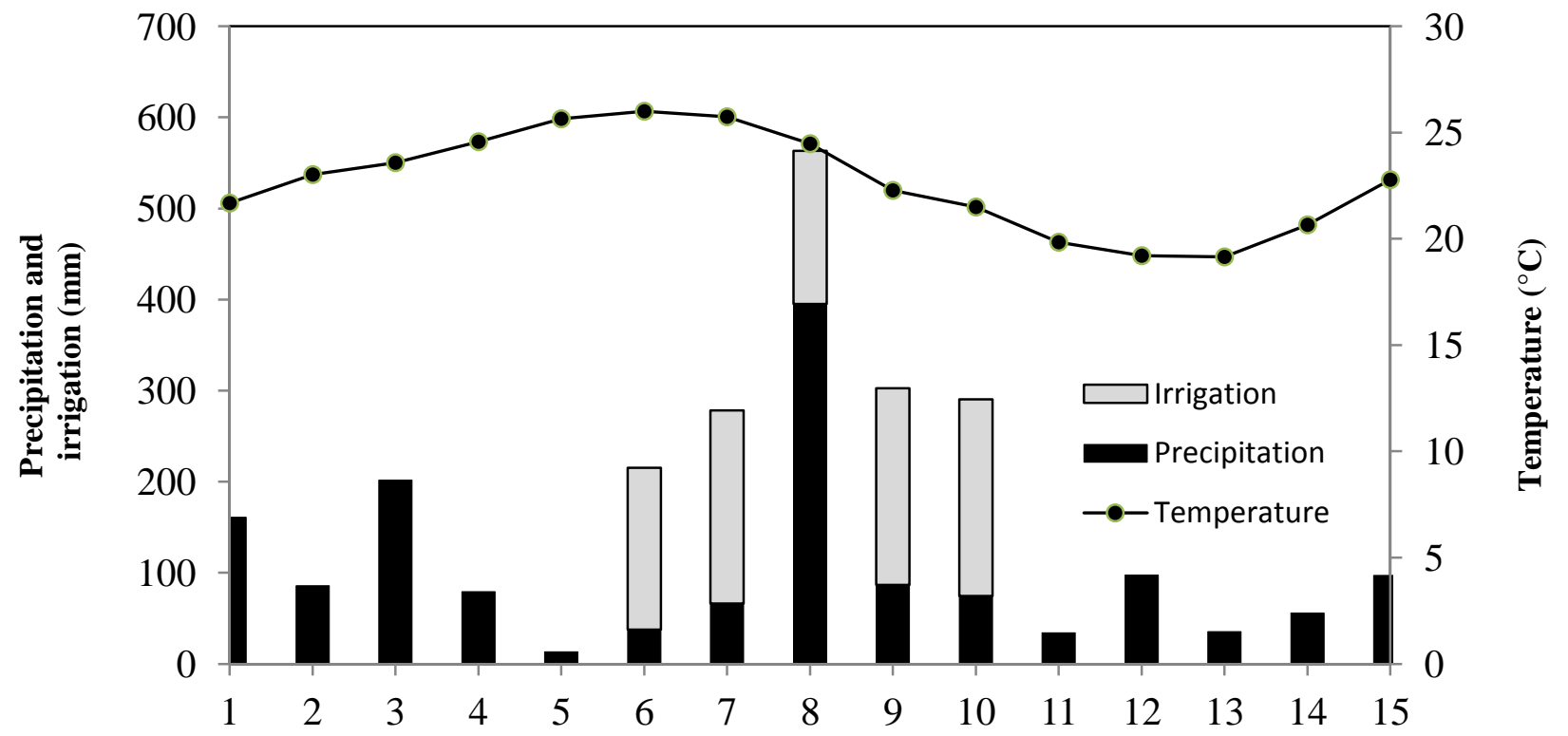

Figure 2 - Monthly water balance (precipitation and irrigation) and average temperature during 2009 and 2010.

Figura 2 - Balanço hídrico mensal (precipitação e irrigação) e a temperatura média durante os anos de 2009 e 2010.

\section{Results and Discussion}

The irrigation increased the biomass by $21 \%$, in terms of Wood Net Primary Production (WNPP). Some of the reasons were: increase in the LUE by $23 \%$ and less carbon allocation to the below-ground (-15\%) (Table 1). Several studies worldwide have demonstrated positive effect of irrigation on Eucalyptus wood production, with stem growth responses of 15-
35\% (CAMPION et al., 2006; STAPE et al., 2008).

Binkley et al. (2004B) showed that in a study with Eucalyptus clonal plantations irrigation increased Gross Primary Production (GPP) from 6.1 to $11.3 \mathrm{~kg} \mathrm{~m}^{-2}$ per year, but the irrigation did not alter the supply of incoming light, but the percentage of light intercepted by the canopy increase from 63 to $71 \%$. In this study, irrigated trees did not increase the APAR, but presented 
higher LUE and higher carbon allocation to wood relative to belowground.

A review showed that LUE generally increases as growth increases in forest plantations (BINKLEY, 2012). In addition, higher LUE could increase the availability of other resources (as water, or nutrients, for example) or change the biomass partitioning, increasing belowground biomass in relation to aboveground biomass. (BINKLEY et al., 2004B; LITTON et al., 2007).

Probably, the higher LUE was due to lower stomatal conductance (gs) in relation to the increase of Vapor Pressure Deficit (VPD) (Figure 3). While LUE in both treatments decreased linearly with increase in VPD, the magnitude of the gs reduction, reflects its sensitivity to VPD, which was higher in the rainfed treatment. Thus, the rainfed treatment showed a decrease of $0.54 \mathrm{~mol} \mathrm{~m}^{2} \mathrm{~s}^{-1}$ in gs for each increase of $1 \mathrm{kPa}$ in $\mathrm{VPD}$, while irrigated treatment was lower, about $0.25 \mathrm{~mol} \mathrm{~m}^{-2} \mathrm{~s}^{-1}$ for each $1 \mathrm{kPa}$ of DPV (Figure 3).

Table 1 - Averages of Wood Net Primary Production (WNPP), Maximum Photosynthesis (Amax), Leaf Area Index (LAI), Absorbed Photo synthetically Active Radiation (APAR), Light Use Efficiency (LUE) and above-ground net primary production / below-ground net primary production ratio (R:A).

Tabela 1 - Médias da produção primária líquida de madeira (WNPP), índice de área foliar (LAI), radiação fotossinteticamente ativa absorvida (APAR), eficiência do uso da luz (LUE) e relação entre produtividade primária líquida abaixo do solo / produtividade primária líquida acima do solo (R:A).

\begin{tabular}{ccccccc}
\hline \multirow{2}{*}{ Treatment } & WNPP & Amax & LAI & APAR & LUE & R:A \\
\cline { 2 - 7 } & $\mathrm{Mg} \mathrm{ha}^{-1} \mathrm{yr}^{-1}$ & $\mu \mathrm{mol} \mathrm{C} \mathrm{m}^{-2} \mathrm{~s}^{-1}$ & $\mathrm{~m}^{2} \mathrm{~m}^{-2}$ & $\mathrm{TJ} \mathrm{ha}^{-1} \mathrm{yr}^{-1}$ & $\mathrm{~g} \mathrm{MJ}^{-1}$ & \multirow{2}{*}{ Ratio } \\
\hline Rainfed & $17,6 \mathrm{a}$ & 14,18 & $3,2 \mathrm{a}$ & $32,7 \mathrm{a}$ & $0,55 \mathrm{a}$ & $0,34 \mathrm{a}$ \\
\hline Irrigated & $21,4 \mathrm{~b}$ & 18,82 & $3,1 \mathrm{a}$ & $31,5 \mathrm{a}$ & $0,68 \mathrm{~b}$ & $0,29 \mathrm{~b}$ \\
\hline
\end{tabular}

* Values followed the same letter in the column are not different at $P=0.05$ of significance.

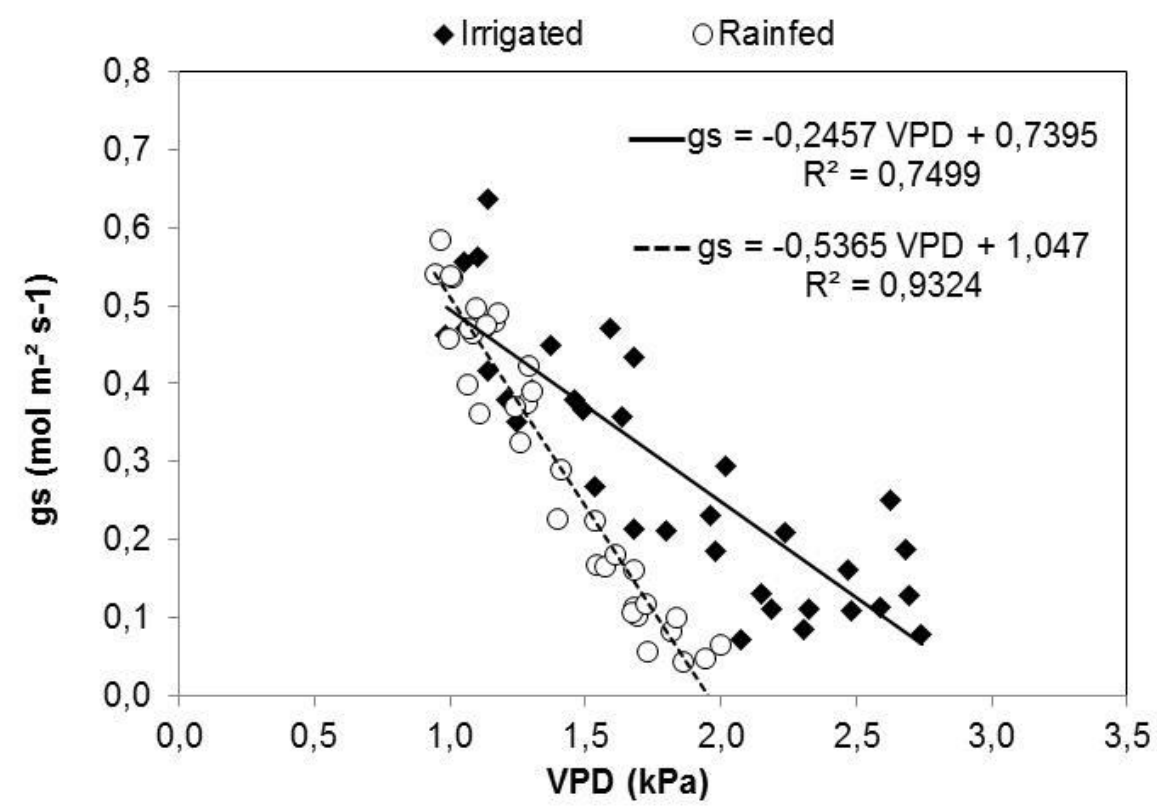

Figure 3 - Relationship between stomatal conductance (gs) and Vapor Pressure Deficit (VPD) in irrigated and rainfed treatments $(n=12)$. *significant at $\mathrm{P}=0.05$.

Figura 3 - Relação entre condutância estomática (gs) e déficit de pressão de vapor nos tratamentos irrigados e não irrigados $(\mathrm{n}=12)$. *significativo a $\mathrm{P}=0.05$. 
In most of the case, stomatal conductance decreases exponentially with increasing VPD (MCCAUGHEY and IACOBELLI, 1994; MONTEITH, 1995). The stomatal closure to the high VPD is reasonable premise that the stomatal response evolved to prevent excessive dehydration and physiological damage, as example, alteration in the normal functioning of photosynthesis, transpiration and respiration of plants (OREN, et al., 1999). While most of the plants exhibit a decline in gs with VPD, there is a variation at the interspecific levels in the sensitivity of the response and Oren et al. (1999) showed that this relationships with and among species are close to the theoretical predictions.

These different behaviors among Eucalyptus clones are commonly found in the field, and can be an alternative to allow us how breeding can use physiological parameters to select more adapted clones to drought conditions.

\section{Conclusions}

The forest plantations future will depend strongly on a range of water-related issues, including rainfall, seasonality of rainfall and vapor pressure deficit, as well as soil water storage capacity (ALMEIDA et al. 2004, STAPE et al. 2004b). The results of this work showed that Eucalyptus is responsive to water supply, and the reduction of stomatal conductance in relation to the VPD variation explains the higher stem biomass increase and greater LUE in the irrigated treatment.

\section{Acknowledgements}

This research was supported by Veracel Celulose SA, the University of São Paulo and Forestry Science and Research Institute (IPEF).

\section{References}

ABRAF (Brazilian Association of Forest Plantation Producers), Yearbook statistical of
ABRAF 2013, ABRAF, Brasília, 150p, 2013.

ALMEIDA, A.C.; LANDSBERG, J.J.; SANDS, P.J. Parameterisation of 3-PG model for fastgrowing Eucalyptus grandis plantations. Forest Ecology and Management, v.193, p.179- 195, 2004.

BINKLEY, D. et al. Light absorption and use efficiency in forests: Why patterns differ for trees and stands, Forest Ecology and Management, v.288, p.5-13, 2013.

BINKLEY, D. A hypothesis about the interaction of tree dominance and stand production through stand development, Forest Ecology Management, v.190, p.265-271, 2004A.

BINKLEY, D.; STAPE, J.L.; RYAN, M. Thinking about resource use efficiency in forests. Forest Ecology and Management, v.193, p.5-16, 2004B.

BINKLEY, D. Understanding the role resource use efficiency in determining the growth of trees and forests. Netherlands: Schlichter, T., Montes, L. (Eds.), Forests in Development: A Vital Balance. Springer, 2012, pp. 13-26.

CAMPION, J.L.; NKOSANA, M.; SCHOLES, M.C. Biomass and $\mathrm{N}$ and $\mathrm{P}$ pools in above and belowground components of an irrigated and fertilized Eucalyptus grandis stand in South Africa. Australian Forestry, v.69, p.48-57, 2006.

LAMBERT, J.H. Photometria, sive de mensura et gradibus luminous, colorum, et umbrae. Basel, 1760.

LITTON, C.M.; RAICH, J.W.; RYAN, M.G. Carbon allocation in forest ecosystems. Global Change Biology, v.13, p.2089-2109, 2007.

MACCAUGHEY, J.H.; IACOBELLI, A. Modelling stomatal conductance in a northen deciduous forest, Chalk River, Ontario. 
Canadian Journal of Forestry Research, v.24, p.904-910, 1994.

MONTEITH, J.L. A reinterpretation of stomatal response to humidity. Plant, Cell and Environment, v.18, p.357-364, 1995.

MORRIS, J.; BENYON, R.; Plantation water use. New Forests: Wood Production and Environmental Services, Collingwood, Austrália, p. 75-104, 2005.

OREN, R. et al. Survey and synthesis of intra and interspecific variation in stomatal sensitivity to vapour pressure deficit. Plant, Cell and Environment, v.22, p.1515-1526, 1999.

RYAN, M.G. et al. Factors controlling Eucalyptus productivity: How water availability and stand structure alter production and carbon allocation, Forest Ecology and Management, v.259, p. 1695-1703, 2010.

SMETHURST P.J. et al. Fertilizer effects on LAI and growth of four Eucalyptus nitens plantations. Forest Ecology and Management, v.76, p.531-542, 2003.

STAPE, J.L.; RYAN, M.G.; BINKLEY, D. Testing the utility of the 3-PG model for growth of Eucalyptus grandis $x$ urophylla with natural and manipulated supplies of water and nutrients, Forest Ecology and Management, v.193, p.219-234, 2004A.

STAPE, J.L. et al. Water use, water limitation and water use efficiency in a Eucalyptus plantation, Bosque, v.25, p.35-41, 2004B.

STAPE, J.L.; BINKLEY, D.; RYAN, M.G. Production and carbon allocation in a clonal Eucalyptus plantation with water and nutrient manipulations, Forest Ecology and Management, v.255, p.920-930, 2008.

WARING, R.H.; THIES, W.G.; MUSCATO, D. Stem growth per unit of leaf area: a measure of tree vigor. Forest Science, v.26, p.112-117, 1980 . 